\title{
Polska przedmurzem chrześcijaństwa
}

Natalia Kulka

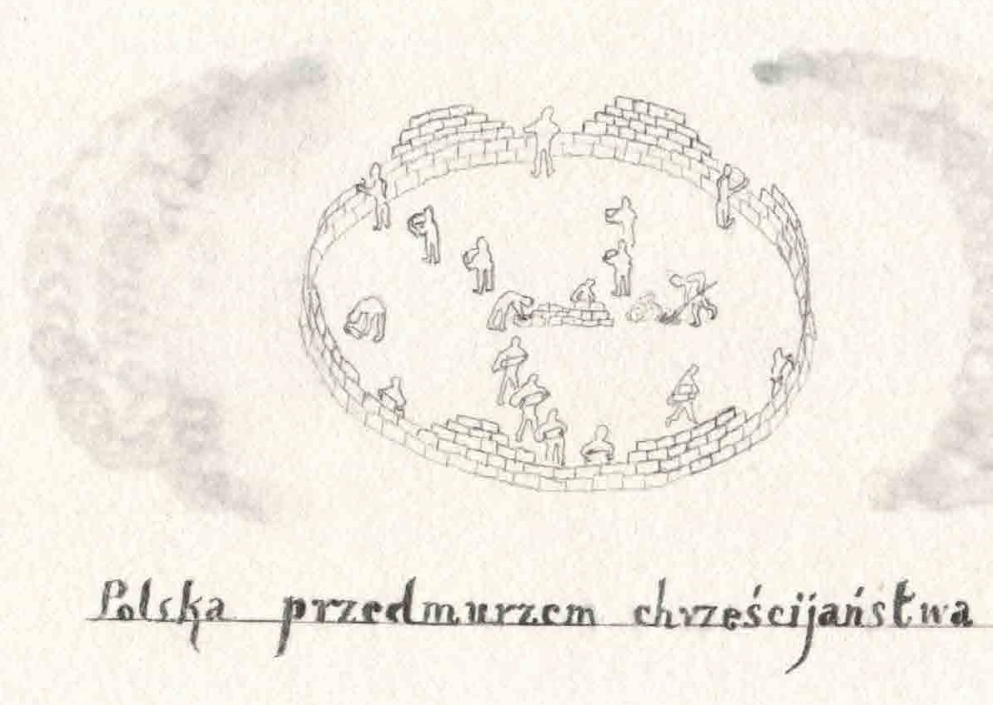

Wyrażenia kluczowe: przedmurze chrześcijaństwa; uchodźcy; granica; kultura polska; wzory kultury; Europa wobec migrantów 


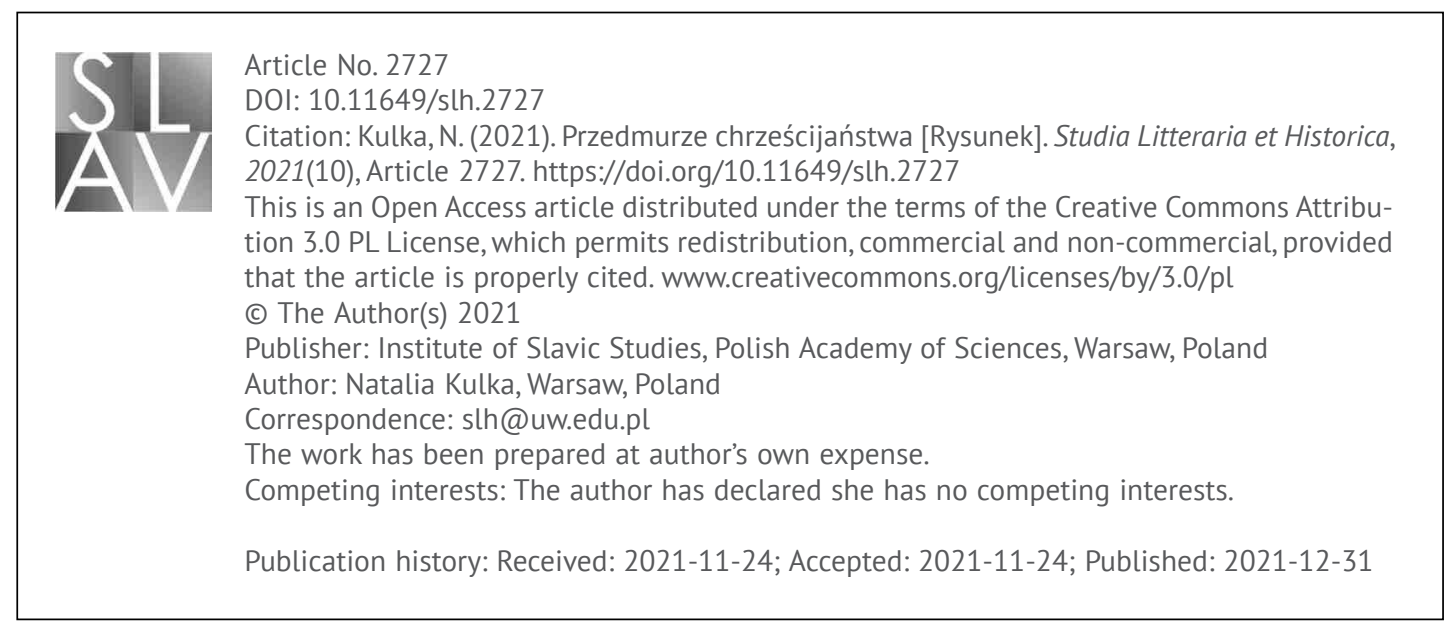

SLH 10/2021 | s. 2 z 2 